\title{
EXTRAHEPATIC AND INTRAHEPATIC VEINS OF THE PORTAL SYSTEM IN THE GROUND SQUIRREL (CITELLUS CITELLUS)
}

\author{
NIKOLIĆ ZORA*, BLAGOJEVIĆ ZDENKA*, VITOROVIĆ D**, ĐELIĆ DIJANA* and NEŠIĆ IVANA*** \\ *Faculty of Veterinary Medicine, University of Belgrade, ** Faculty of Agriculture, University of \\ Belgrade ${ }^{* * *}$ Institute for Virology and Immunology, Torlak, Belgrade \\ (Received 15. September 2002)
}

From studies of the extrahepatic veins and intrahepatic veins of the portal system in the ground squirrel, using anatomical methods and rentgenography, the following can be concluded: The portal vein is formed by the confluence of three venous blood vessels which are present the extrahepatic part of the portal system in the ground squirrel: $V$. gastropancreaticoduodenalis, V. gastrolienalis and V. mesenterica cranialis. V. portae runs towards the portal fissure and divides, upon entering the liver, into a small right branch which is dispersed in the right lobes and a large left branch which ramifies in the remainder of the liver.

$V$. gastropancreaticoduodenalis receives blood from the greater omentum of the stomach ( $V$. gastroepiploica dextra), the cranial part of the duodenum and the right segment of the pancreas $(V$. pancreaticoduodenalis cranialis).

Truncus gastrolienalis drains the parietal and visceral wall of the stomach (V. gastrica sinistra), the spleen and left portion of the greater omentum (V. lienalis).

V. mesenterica cranialis collects blood from the middle part of the duodenum and adjacent part of the pancreas ( $V$. pancreaticoduodenalis media), from the caudal part of the duodenum and the caudal segment of the pancreas ( $V$. pancreaticoduodenalis caudalis), from the jejunum ( $V v$. jejunales) and from the ileum, cecum and colon (Truncus ileocecocolicus).

The extrahepatic veins of the portal system in the ground squirrel are joined through a number of anastomoses.

$V$. portae enters the portal fissure and divides into $V$. advehens lobi dextri lateralis et processus caudatus, $V$. advehens lobi dextri medialis, $V$. advehens processus papillaris, V. advehens lobi quadrati et lobi sinistri medialis and $\mathrm{V} v$. advehentes lobi sinistri lateralis which branch into a large number of smaller vessels in corresponding lobes of the liver. These veins form the intrahepatic part of the portal system in the ground squirrel

Key words: ground squirrel, extrahepatic veins, intrahepatic veins, portal system 


\section{INTRODUCTION}

The ground squirrel (Citellus citellus) is a rodent which lives in Yugoslavia and Macedonia. It is a very interesting hibernating animal and most investigations have been focused in that direction. Thus, the effects of TSH-releasing hormone on neurons of brain in hibernating and active ground squirrel were described (Belousov and Belousova, 1993), as well as changed aortic tissue and persistent circadian rhythmicity in hibernating ground squirrels (Hut et al., 1999, Deelman et al., 1998; Grahn et al.,1994 ) and changed body temperature during hibernation (Hut et al., 2001; Strijkstra, 1999). This was a reason for a systematic study of the organs and organs of systems in the ground squirrel. Our plan involved the liver and its vascularization. Stanojević et al. (1979) have described branches of A.hepatica and a portal vein in the liver of the ground squirrel, but data about extrahepatic veins of the portal system have not been found. The primary purpose of this work was to study the extrahepatic veins of the portal system in the ground squirrel and our results correspond with the system in other experimental rodents.

The portal vein of experimental animals has been the subject of studies by many authors. This includes the portal vein of the rabbit (Barone et al.,1973, Janković, 1960; Dumas, 1953), rat (Blanc,1966; Janković et al.,1962) and molle rat (Blagojević et al.,1989). However, available literature offers very little information on the extrahepatic and intrahepatic veins of the portal system in the ground squirrel.

\section{MATERIAL AND METHODS}

The studies of the portal system in the ground squirrel involved 10 animals of both sexes and various ages. The veins of the portal system was studied after preparing veins from animals previously sacrificed without bleeding. For rentgenography minium solution in linseed oil was injected into the portal vein in situ. The injected blood vessels were X-rayed.

\section{RESULTS AND DISCUSSION}

The portal vein in the ground squirrel arises from a capillary bed and ends in a capillary bed. It collects blood from the pancreas, spleen and all of the gastrointestinal tract except the rectum. The portal vein extends through the hepatoduodenal ligament, ventral to the caudal vena cava. It is about $1-1,5 \mathrm{~cm}$ in diameter at the porta of the liver, where it terminates in a spiral (fig. $\left.2_{1}\right)$, similary to the rat (Hebel and Stromberg,1976). 
Acta Veterinaria (Beograd), Vol. 53. No. 1, 57-63, 2003.

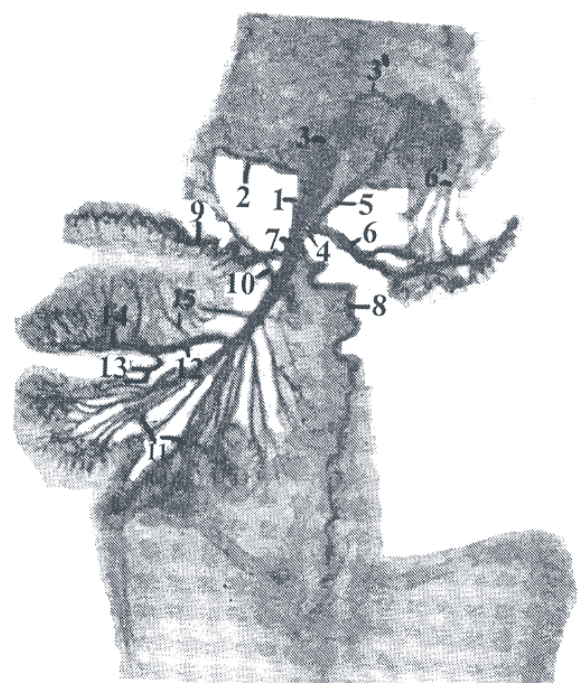

Figure 1. Roentgenogram of extrahepatic veins of the portal system of the liver in the ground squirrel: 1 - V. portae, 2 - V. pancreaticoduodenalis cranialis, 3,3 - V. gastroepiploica dextra, 4 - Truncus gastrolienalis, 5 - V. gastrica sinistra, 6 - V. lienalis, 6- V. gastroepiploica sinistra, 7 - V. mesenterica cranialis, 8 - V. colica sinistra, 9 - V. colica dextra, 10 - Comon truncus for $V$. pancreaticoduodenalis caudalis and V. pancreaticoduodenalis media, $11-V V$. jejunales, 12 - Truncus ileocecocolicus, 13 - ramus ilei, 14 - ramus cecalis, 15 - rami colici

This is triangular in cross section. At the porta, the portal vein gives off branches which enter the liver lobes and further divide intrahepatically. The extrahepatic system in the ground squirrel and molle rat (Blagojević et al. 1989) is formed by the confluence of three vessels (V. gastropancreaticoduodenals, V. gastrolienalis and V. mesenterica cranialis). In the rat (Janković and Stanojević,1962; Hebel and Stromberg, 1976) this system is comprised of four veins (V. gastropancreaticoduodenalis, Truncus gastrolienalis, $V$. colica sinistra and V. mesenterica cranialis).

V. gastropancreaticoduodenalis is the smallest tributary of the portal vein in the ground squirrel. It is 2 to $3 \mathrm{~mm}$ in length and empties into the portal vein about $1 \mathrm{~cm}$ from the portal fissure. It drains blood from the pyloric region of the stomach, from the beginning of the duodenum, right segment of the pancreas and the greater omentum of the stomach. $V$. gastropancreaticoduodenalis in the ground squirrel, molle rat (Blagojević and Nikolić, 1989) and rat (Hebel and Stromberg, 1976) is formed by the fusion of $V$. gastroepiploica dextra and V. pancreaticoduodenalis cranialis.

V. gastroepiploica dextra (Figure $1_{3,3}$ ) is formed from the veins from the cranial part of the duodenum and smaller branches from the right segment of the 
pancreas (rami pancreatici). It also receives a number of smaller branches from the right part of the greater omentum of the stomach and several veins from the greater curvature of the stomach ( $V v$. gastricae breves). Then it extends towards the beginning of the duodenum and right segment of the pancreas (rami pancreatici) and collects blood from them.

V. pancreaticoduodenalis cranialis (Figure $1_{2}$ ) extends through the pancreas and mesoduodenum and drains blood from the right segment of the pancreas and cranial part of the duodenum.

Truncus gastrolienalis (Figure $1_{4}$ ) is a larger branch which participates in forming the portal vein in the ground squirrel, molle rat (Blagojević and Nikolić 1989) and rat (Hebel and Stromberg 1976). This truncus is formed by the confluence of the smaller caudally running V. gastrica sinistra and the larger V. Iienalis. These veins drain blood from the stomach and the spleen.

$V$. gastrica sinistra (Figure $1_{5}$ ) originates from the branches which drain the parietal side (ramus cranialis) and visceral side (ramus caudalis) of the stomach. It also receives small branches from the blind sac of the stomach (Saccus cecus ventriculi). Like the corresponding artery it anastomoses with $V$. gastrica dextra.

$V$. lienalis (Figure $1_{6}$ ) receives blood from the spleen, left segment of the pancreas and left part of the greater omentum. $V$. lienalis arises from two branches which receive tributaries from the long hilus of the spleen. Both branches of the splenic vein receive $V$. gastrica sinistra which evacuates blood from the left part of the greater omentum and Rami pancreatici which drains the left segment of the pancreas.

V. mesenterica cranialis (Figure $1_{7}$ ) is the largest branch of the portal vein in the ground squirrel, molle rat (Blagojević and Nikolić,1989) rat (Janković and Stanojević, 1962) and rabbit (Barone et al.,1973). It is about $2 \mathrm{~mm}$ in diameter and runs along the corresponding artery. In the ground squirrel this large blood vessel arises from the confluence of $V$. colica sinistra, V. colica dextra, V. pancreaticoduodenalis media, V. pancreaticoduodenalis caudalis, Vv. jejunales and Truncus ileocecocolicus.

V. colica sinistra (Figure $1_{8}$ ) is a long vein, about $4 \mathrm{~mm}$ in length. It extends through the left mesocolon. It originates from 10 to 15 branches which drain blood from the colon descendens. The last branch of the colic vein drains blood from the rectum. V. colica sinistra in the ground squirrel and molle rat (Blagojević and Nikolić,1989) leads blood into the V. mesenterica cranialis, but in the rat (Janković and Stanojević, 1962) it takes blood directly into the portal vein.

$V$. colica dextra ( Figure $1_{9}$ ) is comprised of many branches which collect blood from the colon transversum and caudal part of the colon ascendens. It takes blood into V. mesenterica cranialis. V. colica dextra in the molle rat (Blagojević and Nikolić,1989) and rat (Janković and Stanojević,1962) differs from in the ground squirrel by draining blood from the colon into $\mathrm{V}$. ileocecocolica.

$V$. pancreaticoduodenalis media (Figure $1_{10}$ ) is formed from two branches which drain blood from the middle part of the duodenum and corresponding segment of the pancreas. These two branches also anastomose with $V$. pancreaticoduodenalis cranialis. 
Acta Veterinaria (Beograd), Vol. 53. No. 1, 57-63, 2003.

Nikolić Zora et al. Extrahepatic and intrahepatic veins of the portal system in the ground squirrel (Citellus citellus)

V. pancreaticoduodenalis caudalis (Figure $1_{10}$ ) originates from a number of tiny veins which drain blood from the caudal part of the duodenum and a segment of the pancreas.

As in the molle rat $V v$. jejunales (Figure $1_{11}$ ), the jejunal trunk, in the ground squirrel is most frequently composed of 5 to 10 jejunal veins. These veins drain blood from the jejunum.

Truncus ileocecocolicus (Figure $1_{12}$ ) is the end of the cranial mesentery artery. It arises from the confluence of ramus ilei (Figure $1_{13}$ ) ramus cecalis (Figure $1_{14}$ and rami colici (Figure $1_{15}$ ) draining blood from the respective organs. Truncus ileocecocolicus in the molle rat (Blagojecić and Nikolić, 1989) and rat (Hebel and Stromberg, 1976) differs from that in the ground squirrel by arising from the confluence of $V$. ilei, $V$. colica dextra and $V$. cecalis.

The portal vein ( $V$. portae) enters the portal fissure on the liver in the area of the right lateral lobe together with the hepatic artery ( $A$. hepatica). Branches of different sizes separate from it and ramify in different lobes of the liver. The vein blood of the rabbit (Janković,1960) and rat (Hebel and Stromberg,1976) is brought to the liver by two branches of the portal vein. Ramus dexter is a smaller and thinner branch than ramus sinister. Ramus dexter ramifies into the right lateral lobe and caudat processus. Ramus sinister ramifies into the other lobes of the liver. The intrahepatic ramification of the portal vein in the ground squirrel is conditioned by the lobar structure of its liver. Namely, the liver in the ground squirrel is divided into lobus dexter lateralis, lobus dexter medialis, lobus quadratus, lobus sinister medialis, lobus sinister lateralis and lobus caudatus with processus papillaris and processus caudatus (Stanojević et al.,1978).

V. advehens lobi dextri lateralis and processus caudatus (Figure $2_{2}$ ) is the first vein of the intrahepatical veins of the portal system in the ground squirrel. About 5 to $6 \mathrm{~mm}$ from its beginning it divides into two branches of which one extends to the right lateral lobe (Figure $2_{2}$ ) and the second towards caudat processus (Figure $2{ }_{2}^{\prime \prime}$ ). In the rabbit (Janković 1960; Hebel and Stromberg 1976)) ramus dexter of the portal vein brings the portal blood into the right lateral lobe and caudat processus.

$V$. advehens lobi dextri medialis (Figure $2_{3}$ ) extends along cystic ductus on the visceral surface of the medial lobe and then it enters the right medial lobe dividing into a large number of branches.

$V$. advehens processus papillaris (Figure $2_{5}$ ) is a branch which emerges from the dorsal wall of the portal vein, enters papillar processus and divides into several little branches.

$V$. advehens lobi quadrati et lobi sinistri medialis (Figure $2_{4}$ ) is a trunk which lies superficially between the quadratus and the left medial lobe. It divides into two branches Figure $\left.2_{4}^{\prime}, 4^{\prime \prime}\right)$ which bring the portal blood into the respective lobes.

$V v$. advehentes lobi sinistri lateralis (Figure $2_{6}$ ) represents four veins between the left lateral lobe and the left medial lobe. These four branches of the portal vein bring the portal blood into the dorsal, medial and ventral parts of the left lateral lobe. 


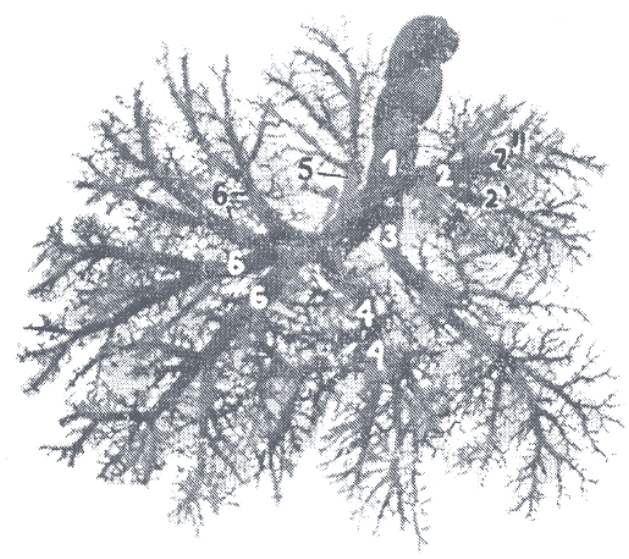

Figure 2. Roentgenogram of intrahepatic branches of the portal vein in the ground squirrel: 1 - V. portae, 2 - V. advehens lobi dextri lateralis et processus caudatus, 2 - branch for lobus hepatis dexter lateralis, 2 - branch for processus caudatus, $3-\mathrm{V}$. advehens lobi dextri medialis, 4 - V. advehens lobi quadrati et lobi sinistri medialis, 4 - branch for lobus quadratus, 4" - branch for lobus hepatis medialis sinister, 5 - V. advehens processus papillaris, 6 - Vv. advehentes lobi sinistri lateralis

Address for correspondence:

Prof Dr Zora Nikolić,

Faculty of Veterinary Medicine,

University of Belgrade,

Bulevar JNA 18,

11000 Belgrade, Serbia \& Montenegro

\section{REFERENCES}

1. Barone R, Pavaux C, Blin PC, Cuq P,1973. Atlas d'Anatomie du lapin (Atlas of Rabbit).

2. Belousov $B$, Belousova $V, 1993$. Effects of thyrotropin/releasing hormone on the activity of septal neurons in brain slices of the hibernating and active ground squirrels, Citellus undulatus. $J$ Evol Biochem Physiol 29, 2, 98-102.

3. Blagojević Z, Nikolić Z. 1989. Extrahepatic veins of the portal system in the molle rat (Spalax leucodon), Acta veterinaria (Beograd), 39, 5-6, 357-64.

4. Blanc B. 1966. Le systeme de la veine porte du Hamster dore et du Rat blanc These de doctorat veterinaire, Alfort. France.

5. Booz HK, 1959. Experimentalle und morphologische Beobachtungen an der Vena portae der weissen Ratte. Univestitat d. Saarlandes Med. Dissertation.

6. Deelman LE, Henning RH, Hut RA, Van der Zee EA, Epema AH. 1998. Changed responsiveness of aortic tissue in hibernating ground squirrels. Anesthesiol, 89, 440

7. Dumas J. 1953. Les animaux de laboratorie. Collection de L' Instititut Pasteur, Paris. Baltimore, USA.

8. Grahn DA, Miller JD, Houng VS, Heller HC, 1994. Persistence of cardian rhythmicity in hibernating ground squirrels, Am J Physiol, 266, 1251-8.

9. Hebel R, Stromberg MW, 1976. Anatomy of the laboratory rat. The William-Wilkins Company. 
Acta Veterinaria (Beograd), Vol. 53. No. 1, 57-63, 2003

Nikolić Zora et al. Extrahepatic and intrahepatic veins of the portal system in the ground squirrel (Citellus citellus)

10. Hut RA, Barnes BM, Daan S, 2001. Body temperature patterns before, during and after seminatural hibernation in the European ground squirrel, J Comp Physiol, B, 172, 1007-12.

11. Hut RA, Van Oort BEH, Daan S, 1999. Natural entrainment without dawn and dusk: the case of the European ground squirrel (Spermophilus citellus), J Biol Rhyt 14, 290-9.

12. Janković Ž. 1960. Prilog poznavanju lobarne građe i vena jetre kunića (Oryctolagus cuniculus). Acta veterinaria (Beograd), X, 3, 41-56

13. Janković Ž, Stanojević D, 1962. Ekstrahepatične vene portalnog krvotoka u belog pacova, Acta veterinaria, XII.I, 55-64.

14. Stanojević D, Janković Ž., Nikolić Z, 1979. Blood vessels of the liver in the ground squirrel (Citellus citellus L.). Acta veterinaria (Beograd), 29, 3-4, 129-36.

15. Stanojević D, Janković, Nikolić Z, 1978. The liver in the ground squirrel (Citellus citellus) and its bile ducts, Acta veterinaria (Beograd), 28, 2, 97-106.

16. Strijkstra $A M, 1999$. Periodic euthermy during hibernation in the European ground squirrel: causes and consequences. PhD Thesis, Rijksuniversiteit Groningen, The Netherland.

\section{EKSTRAHEPATIČNE I INTRAHEPATIČNE VENE PORTALNOG KRVOTOKA JETRE U TEKUNICE (CITELLUS CITELLUS)}

NIKOLIĆ ZORA, BLAGOJEVIĆ ZDENKA, VITOROVIĆ D, ĐELIĆ DIJANA i NEŠIĆ IVANA

$$
\text { SADRŽAJ }
$$

$\mathrm{Na}$ osnovu proučavanja ekstrahepatičnih i intrahepatičnih vena portalnog krvotoka jetre u tekunice, koristeći anatomske metode i rentgenolografiju, mogu se izvesti sledeći zaključci:

Vena portae nastaje iz sliva tri venska krvna suda koja čine extrahepatični deo portalnog krvotoka u tekunice: $V$. gastropancreaticoduodenalis, $V$. gastrolienalis i $V$. mesenterica cranialis. $V$. portae se pruža prema portalnom žlebu i po ulasku u jetru deli se na manju, desnu granu koja se razgranava u desne režnjeve jetre i veću, levu granu koja se razgranava u ostale režnjeve jetre.

$V$. gastropancreaticododenalis odvodi krv iz omentum majus-a ( $V$. gastroepiploica dextra), početnog dela duodenuma i desnog režnja pankreasa (V. pancreaticoduodenalis cranialis)

Truncus gastrolienalis odvodi krv iz parijetalnog i visceralnog zida želudca (V. gastrica sinistra) i slezine i levog dela omentum majus-a (V. lienalis).

$V$. mesenterica cranialis odvodi krv iz srednjeg i završnog dela duodenuma i odgovarajućeg dela pankreasa (V. pancreaticoduodenalis media), iz kaudalnog dela duodenuma i kaudalnoig dela pankreasa ( $V$. pancreaticoduodenalis caudalis) iz jejunuma ( $V v$. jejunales) i iz ileuma, cekuma i kolona (Truncus ileocecocolicus).

Ekstrahepatične vene portalnog krvotoka jetre tekunice stoje u vezi preko mnogobrojnih anastomoza.

$V$. portae ulazi u portalni žleb i iz nje izbijaju vene (V. advehens lobi dextri lateralis et processus caudatus, $V$. advehens lobi dextri medialis, $V$. advehens processus papillaris, $V$. advehens lobi quadrati et lobi sinistri medialis and $V V$. advehentes lobi sisnistri lateralis) koje se razgranavaju u odgovarajućim režnjevima jetre tekunice i čine intrahepatični deo portalnog krvotoka tekunice. 